\title{
An Estimate of Production and Consumption Rates in the Spiny Lobster Panulirus homarus on a Shallow Littoral Reef off the Natal Coast, South Africa
}

\author{
P. F. Berry* and M. J. Smale** \\ Oceanographic Research Institute, 2 West Street, Durban, South Africa 4001
}

\begin{abstract}
Production and consumption rates were studied in a population of the spiny lobster Panulirus homarus (Linnaeus) inhabiting an isolated reef. Estimated mean production rate $(P)$ (comprising somatic tissue, unliberated gonadal products and exoskeleton) was $47.6 \mathrm{~kJ} \mathrm{~m}^{-2} \mathrm{y}^{-1}$ or, in terms of dry mass, $2.1 \mathrm{~g} \mathrm{~m}^{-2} \mathrm{y}^{-1}$ (P/B $\left.: 0.42\right)$. Mean gonadal output $(G)$ was $9.8 \mathrm{~kJ} \mathrm{~m}^{-2} \mathrm{y}^{-1}$ of which egg production comprised about $90 \%$. Nevertheless, total production rate $(P+G)$ was approximately equal in the sexes suggesting that the slower growth rate and lower value for $P$ in females is directly proportional to energy loss by egg production. The energy lost through moulted exuviae (conventionally assigned to excreta $(U)$ in the energy budget) was determined using the same basic method as for determination of $P$ and amounted to $28.1 \mathrm{~kJ} \mathrm{~m}^{-2} \mathrm{y}^{-1}$. On the basis of the consumption rate of flesh of the mussel Perna perna in captive lobsters (the principal food organism of $P$. homarus) it was estimated that the reef population consumed $1070 \mathrm{~kJ} \mathrm{~m}^{-2} \mathrm{y}^{-1}$. The food in the form of mussels on the reef was substantially in excess of the requirements of the lobster population although an unknown proportion may be physically unavailable.
\end{abstract}

\section{INTRODUCTION}

This study forms part of a programme in which the ecology of a shallow subtropical reef community on the Natal coast is being investigated in terms of energy flow. The area chosen for the project is a small isolated reef with a surface area of $1646 \mathrm{~m}^{2}$, situated in front of the Oceanographic Research Institute (ORI), Durban, and known as the ORI Reef. A prolific and varied fauna is present on it which is regarded as being typical of shallow subtidal reefs in the nearshore zone of Natal.

The spiny lobster Panulirus homarus has the highest mean annual biomass of the invertebrate carnivores present on the ORI Reef and feeds largely on the brown mussel Perna perna which is the dominant filter feeder present (Berry, 1971, 1978). An attempt is made here to assess the consumption and production rates of the lobster population, production being defined as the total assimilated food or energy incorporated into tis-

\footnotetext{
- Present address: Western Australian Museum, Francis Street, Perth, W. Australia 6000.

- Present address: Port Elizabeth Museum, Humewood Port Elizabeth, S. Africa 6001.
}

total assimilated food or energy incorporated into tissue during any time interval $\Delta t$ including that by individuals which do not survive to the end of $\Delta t$ (Ivlev, 1966). Production $(P)$, comprising growth of somatic tissue, unliberated gonadal material and an element of the exoskeleton, was distinguished from production of liberated gonadal material (G). Energy lost in the production of moulted exuviae was also determined being closely associated with the growth process although this is assigned to excreta $(U)$ following I.B.P. convention (Crisp, 1971).

\section{MATERIALS AND METHODS}

Mean annual biomass of Panulirus homarus (Linnaeus) was determined on the basis of samples taken approximately quarterly over three consecutive years. Every lobster larger than $20 \mathrm{~mm}$ carapace length was collected from the reef by divers using SCUBA, measured to the nearest $\mathrm{mm}$ (carapace length) and returned. Wet mass $(\gamma)$ was obtained by conversion from carapace length $(\chi)$ using the regressions $\gamma=$ $0.00253 \chi^{2.78}$ for males and $\gamma=0.00177 \chi^{2.86}$ females calculated by Berry (1971). An analysis of variance 
showed that the error introduced by this conversion did not exceed $6 \%$ which is unlikely to be greater than that of direct measurement of wet mass. Conversion to acid treated dry mass $(\gamma)$ from carapace length $(\chi)$ was obtained from the equations $\gamma=4.6517 \times 10^{-4} \chi^{2.78}$ for males and $\gamma=3.3646 \times 10^{-4} \chi^{2.86}$ for females. The ratio of whole animal wet mass to acid treated dry mass is 5.60: 1 (Smale, 1978).

Panulirus homarus breeds throughout the year; consequently, cohorts or year classes are indistinguishable (Berry, 1971). Production rate (P) was therefore estimated for individual size classes using the method described by Ricker (1968) and the formula derived by Ricker (1946) and Allen (1950), $P=G \bar{B}$. Taking growth to be exponential, its instantaneous coefficient $G$ was estimated by:

$$
G=\frac{\log _{e} \bar{W}_{2}-\log _{e} \bar{W}_{1}}{t}
$$

where $\bar{W}_{1}$ and $\bar{W}_{2}$ are the mean weights at times $t_{1}$ and $t_{2}$, respectively. The growth rate of $P$. homarus determined by Berry (1971) was used to compute $\bar{W}_{1}$ and $\bar{W}_{2}$.

Taking a straight line rather than an exponential curve as adequately representing change in mean biomass over the time intervals used, $\bar{B}$ was estimated by

$$
\bar{B}=\frac{B_{1}+B_{2}+B_{3}+B_{4}}{4}
$$

where $B_{1}, B_{2}, B_{3}$ and $B_{4}=$ the biomass at times $t_{1}, t_{2}, t_{3}$ and $t_{4}$, respectively.

The same basic method was applied in estimation of whole-animal production, production of exoskeletons (exuviae), and gonadal output. In the latter, however, a complication arises in that Panulirus homarus breeds repetitively, the number of broods of eggs produced per year increasing progressively up to a maximum of 4 with increase in size of females (Berry, 1971). On the basis of the proportion of time during the year that the majority of females in each size class are carrying eggs and knowledge of their mean intermoult period it was possible to obtain a rough approximation of the proportions in each size class that produce 1, 2, 3 or 4 broods

Table 1. Panulirus homarus. Percentage of females producing

\begin{tabular}{|c|c|c|c|c|}
\hline \multirow{2}{*}{$\begin{array}{l}\text { Size class } \\
(\mathrm{mm})\end{array}$} & \multicolumn{4}{|c|}{ Number of broods } \\
\hline & 1 & 2 & 3 & 4 \\
\hline $50-59$ & 50 & 45 & 5 & 0 \\
\hline $60-69$ & 25 & 60 & 15 & 0 \\
\hline $70-79$ & 15 & 20 & 60 & 5 \\
\hline $80-89$ & 5 & 15 & 70 & 10 \\
\hline $90-99$ & 5 & 10 & 75 & 10 \\
\hline
\end{tabular}
$1,2,3$ or 4 broods of eggs per year in each size class per annum (Berry, 1971). Production was, therefore corrected for repetitive breeding using the estimates of these proportions given in Table 1.

It was also necessary to take into account that in the $50-59 \mathrm{~mm}$ size class only approximately $75 \%$ of the population are sexually mature and breed at all.

Dry egg mass ( $\gamma$ ) was obtained by conversion from carapace length $(\chi)$ using the formula $\gamma=1.1069 \times$ $10^{-4} \chi^{2.93}\left(n=153 ; r^{2}=0.88\right)$.

In the case of males, repetitive mating must also occur and in the absence of any data on its frequency the same correction was applied for each size class as was for egg production. Panulirus homarus males produce a large spermatophoric mass which is deposited on the females' sternum (Berry, 1970). Wet mass ( $\gamma$ ) was obtained from the following regression on carapace length $(\chi): y=5.7108 \times 10^{-9} \chi^{4.67}\left(n=152 ; r^{2}=0.71\right)$. The ratio of wet spermatophoric mass to dry mass is $1.93: 1$

Exuviae were acid treated $\left(7 \% \mathrm{HNO}_{3}\right)$ to remove $\mathrm{CaCO}_{3}$ and conversion from carapace length $(\chi)$ was effected using the regression $\gamma=2.4737 \times 10^{-5} \chi^{3.06}(n$ $=137 ; r^{2}=0.92$ ), which was calculated for both sexes combined. In determination of the production rate of exuviae it was necessary for each size class to take into account the number of times the lobsters moulted annually and the mean growth increment. The exoskeletons grow from an initial mass $\left(\bar{W}_{1}\right)$ to successive masses $\left(\bar{W}_{2}, \bar{W}_{3}, \bar{W}_{4}\right.$, etc.) at respective moults during a year. Thus instead of the instantaneous growth coefficient $G$ being simply: $\log \bar{W}_{2}-\log \bar{W}_{1}$, where $\bar{W}_{1}$ is the initial mass and $\bar{W}_{2}$ the mass at the end of the year, $G$ was obtained by calculating instantaneous growth coefficients for each successive moult and summing them, i.e.

$$
G=\sum_{x=n}^{x=1} \log \bar{W} \mathrm{~b}(x)-\log \bar{W} \mathrm{a},
$$

where $a=$ initial mass, $b=$ mass at $\mathrm{n}$ successive moults.

Consumption rate (C) for Panulirus homarus fed on excess quantities of mussel Perna perna (its chief food organism) and held at various temperature regimes in tanks was determined by Smale (1978). The rate he obtained for lobsters held at ambient temperature with sea water was applied to each quarterly sample of the population, enabling the annual consumption rate to be computed for the ORI Reef population over the three years of study.

Calorific values were determined using an adiabatic bomb calorimeter on tissue that had been dried to constant mass at $60^{\circ} \mathrm{C}$. The following ash-inclusive calorific values were applied: whole animal (acid treated), $22.266 \mathrm{~kJ} \mathrm{~g}^{-1}$; acid treated exoskeleton, $18.350 \mathrm{~kJ} \mathrm{~g}^{-1}$; spermatophoric mass, $27.906 \mathrm{~kJ} \mathrm{~g}^{-1}$; eggs, $33.270 \mathrm{~kJ} \mathrm{~g}^{-1}$. 


\section{RESULTS}

Numbers of Panulirus homarus captured from the ORI Reef in quarterly samples are presented in Table 2. A considerably higher mean number was recorded in the first year than in the subsequent two years. The numbers for the three years sampled ranged from 353.5 $\left(0.21 \mathrm{~m}^{-2}\right)$ to $129.5\left(0.08 \mathrm{~m}^{-2}\right)$ with a mean of 206.5 $\left(0.13 \mathrm{~m}^{-2}\right)$. The size frequency distributions of the samples conformed closely to those of much larger samples taken by Berry (1971) and are considered to reflect the typical population composition of $P$. homarus on nearshore reefs in Natal.

Mean biomass on an annual basis is summarized in Table 5. A substantially higher biomass was recorded in $1974 / 75$ than in the following two years. The fact that the biomass in $1976 / 77$ was slightly lower than for 1975/76, despite higher numbers, reflects the somewhat smaller size composition of the lobster population that year. The mean dry biomass over the three years was $5.03 \mathrm{~g} \mathrm{~m}^{-2}\left(112.02 \mathrm{~kJ} \mathrm{~m}^{-2}\right)$.

Estimates of whole animal production $\left(P_{1}\right)$, production of exoskeleton (exuviae) $\left(P_{2}\right)$ and gonadal output corrected for repetitive breeding $\left(P_{3}\right)$ by both sexes each year are presented in Tables 3 and 4 with data used for computation of $\left(P_{1}\right)$ given in full in Table 3 . In Table 5 annual production rates $\left(\mathrm{kJ} \mathrm{m}^{-2} \mathrm{y}^{-1}\right)$ and $P \bar{B}$ ratios for $P_{1}, P_{2}$, and $P_{3}$ are summarised with $P_{2}$ and $P_{3}$ expressed as percentages of $P_{1}$.

Over the three years the mean whole animal production rate $\left(P_{1}\right)$ for both sexes was $47.63 \mathrm{~kJ} \mathrm{~m}^{-2} \mathrm{y}^{-1}$ (2.14 $\mathrm{g} \mathrm{m}^{-2} \mathrm{y}^{-1}$ dry mass) with a range of

Table 2. Panulirus homarus. Numbers captured from ORI Reef in quarterly samples over three consecutive years

\begin{tabular}{|c|c|c|c|}
\hline Month & $\begin{array}{c}\text { Number of } \\
\text { males }\end{array}$ & $\begin{array}{l}\text { Number of } \\
\text { females }\end{array}$ & Total \\
\hline Jul. 1974 & 316 & 264 & 580 \\
\hline Oct. 1974 & 113 & 89 & 202 \\
\hline Jan. 1975 & 186 & 131 & 322 \\
\hline May 1975 & 144 & 166 & 310 \\
\hline Total & 759 & 655 & 1414 \\
\hline Aug. 1975 & 44 & 47 & 91 \\
\hline Oct. 1975 & 80 & 56 & 136 \\
\hline Mar. 1976 & 67 & 58 & 125 \\
\hline May 1976 & 92 & 74 & 166 \\
\hline Total & 283 & 235 & 518 \\
\hline Jul. 1976 & 97 & 77 & 174 \\
\hline Oct. 1976 & 38 & 28 & 66 \\
\hline Apr. 1977 & 105 & 105 & 210 \\
\hline June 1977 & 56 & 40 & 96 \\
\hline Total & 296 & 250 & 546 \\
\hline
\end{tabular}

84.95-27.85 $\mathrm{kJ} \mathrm{m}^{-2} \mathrm{y}^{-1}$. The mean $P / \bar{B}$ ratio for the sexes combined was 0.42 , the slightly higher ratio in $1976 / 77$ probably being attributable to the smaller size composition of the population in that year. The mean $P / \bar{B}$ ratio for males was 0.43 and for females 0.42 .

The mean annual production of exuviae $\left(P_{2}\right)$ was $28.14 \mathrm{~kJ} \mathrm{~m}^{-2} \mathrm{Y}^{-1}\left(59.07 \%\right.$ of $\left.P_{1}\right)$.

The mean annual gonadal output $\left(P_{3}\right)$ was 9.83 $\mathrm{kJ} \mathrm{m} \mathrm{m}^{-2} \mathrm{y}^{-1}\left(20.64 \%\right.$ of $\left.P_{1}\right)$. Mean egg production rate comprised $90.8 \%$ of total gonadal output. In 1976/77, egg production rate was only $8.65 \%$ of $P_{1}$ as opposed to about $25 \%$ in the previous two years. This again can probably be attributed to the smaller size composition of the population in $1976 / 77$. Mean total production $\left(P_{1}\right.$ $+P_{3}$ ) was $57.46 \mathrm{~kJ} \mathrm{~m}^{-2} \mathrm{y}^{-1}$. For the three years total production $\left(\mathrm{kJ} \mathrm{m}^{-2} \mathrm{y}^{-1}\right)$ for males and females respectively was: 50.8 and $53.3(1974 / 75), 18.2$ and 19.5 $(1975 / 76)$, and 16.1 and $14.13(1976 / 77)$.

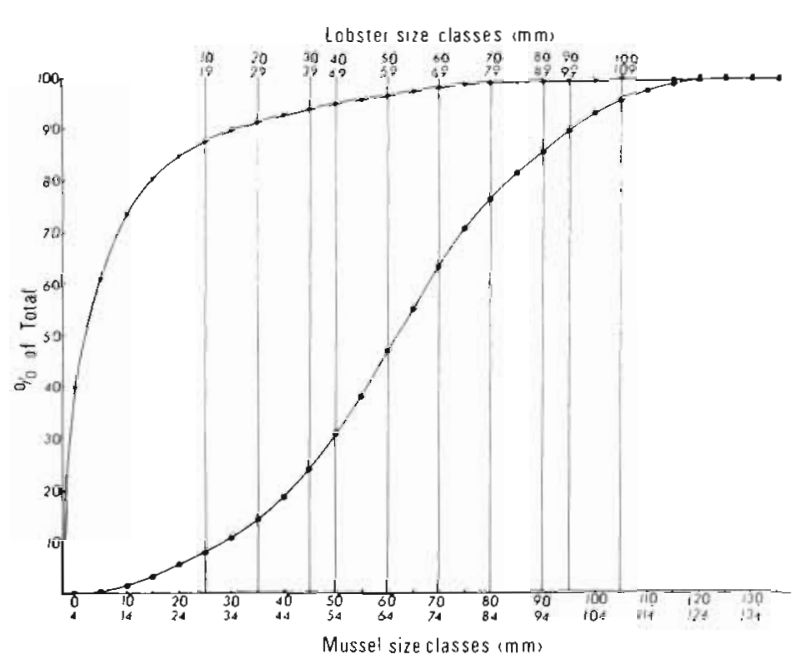

Fig. 1. Calculated proportion of mean standing crop of Perna perna potentially available as food for Panulirus homarus on the ORI Reef. Proportion plotted as cumulative percentage of total with increase in size in terms of biomass (circles) and numbers (triangles). Vertical lines indicate availability or non-availability of mussels to different-sized lobsters in terms of the maximum mussel size they are, capable of opening

Panulirus homarus in Natal feeds principally on the mussel Perna perna (Berry, 1971). This was confirmed on the ORI Reef where it was found to constitute $85.3 \%$ of the dry mass of food in lobster foreguts. Estimates of consumption rates (C) of the Panulirus homarus population over the three consecutive years sampled, based on the consumption rate of $P$. perna flesh obtained by Smale (1978) in captive animals were $1808.3 \mathrm{~kJ} \mathrm{~m}^{-2} \mathrm{y}^{-1}$, $770.9 \mathrm{~kJ} \mathrm{~m}^{-2} \mathrm{y}^{-1}$ and $631.8 \mathrm{~kJ} \mathrm{~m}^{-2} \mathrm{y}^{-1}$, respectively. The mean was $1070.3 \mathrm{~kJ} \mathrm{~m}^{-2} \mathrm{y}^{-1}$; Smale's consumption-rate data were, however, supplemented with additional 
data to cover the size range of lobsters encountered on the ORI Reef. Total production rate, therefore, represents a mean of $5.4 \%$ of total consumption rate, a value which appears to be low but which cannot be evalu- ated until the other components of the energy equation are available.

Smale (1978) showed in tank studies that the maximum size mussel that a rock lobster is physically

Table 3. Panulinis homarus. Female annual production rates $\left(P_{1}\right)$ (with data used to calculate them); production rates of dry exoskeleton (exuviae) organics $\left(P_{2}\right)_{i}$ and gonadal output corrected for repetitive breeding $\left(P_{3}\right)$ for each carapace length size class for $1974 / 75$. Totals only of each are presented for $1975 / 76$ and $1976 / 77$

\begin{tabular}{|c|c|c|c|c|c|c|c|c|}
\hline $\begin{array}{l}\text { Size class } \\
\quad(\mathrm{mm})\end{array}$ & $\bar{W}_{1}$ & $\bar{N}$ & $\bar{W}_{2}$ & $\left(\log \frac{G}{\left.\bar{W}_{2}-\log \bar{W}_{1}\right)}\right.$ & $\bar{B}$ & $P_{1}$ & $P_{2}$ & $P_{3}$ \\
\hline $25-29$ & 23.07 & 5.25 & 178.02 & 2.04 & 121.12 & 247.08 & 34.12 & 0 \\
\hline $30-34$ & 37.19 & 5.25 & 187.23 & 1.62 & 195.25 & 316.31 & 48.63 & 0 \\
\hline $35-39$ & 55.99 & 8.25 & 194.81 & 1.25 & 461.92 & 577.40 & 100.76 & 0 \\
\hline $40-44$ & 80.08 & 12.75 & 202.59 & 0.93 & 1021.02 & 949.55 & 143.80 & 0 \\
\hline $45-49$ & 110.06 & 14.25 & 225.03 & 0.72 & 1568.36 & 1129.22 & 136.95 & 0 \\
\hline $50-54$ & 146.52 & 24.50 & 255.83 & 0.56 & 3589.74 & 2010.25 & 283.48 & 52.64 \\
\hline $55-59$ & 190.05 & 22.75 & 316.11 & 0.51 & 4323.64 & 2205.06 & 231.42 & 60.89 \\
\hline $60-64$ & 241.21 & 20.25 & 352.94 & 0.38 & 4884.50 & 1856.11 & 264.00 & 136.44 \\
\hline $65-69$ & 300.57 & 15.25 & 425.09 & 0.35 & 4583.69 & 1604.29 & 222.30 & 114.03 \\
\hline $70-74$ & 368.71 & 18.25 & 524.28 & 0.35 & 6728.96 & 2355.14 & 324.40 & 276.54 \\
\hline $75-79$ & 446.16 & 9.00 & 581.01 & 0.26 & 4015.44 & 1044.01 & 127.72 & 118.51 \\
\hline $80-84$ & 533.48 & 4.50 & 631.21 & 0.17 & 2400.66 & 408.11 & 65.34 & 64.18 \\
\hline $85-89$ & 6.31 .21 & 1.75 & 688.51 & 0.09 & 1104.62 & 99.42 & 26.70 & 27.87 \\
\hline $90-94$ & 739.90 & 1.50 & 770.02 & 0.04 & 1109.85 & 44.39 & 25.62 & 11.10 \\
\hline $95-99$ & 860.08 & 0.25 & 872.75 & 0.01 & 215.02 & 2.15 & 4.00 & 2.14 \\
\hline \multirow{4}{*}{\multicolumn{2}{|c|}{ Totals $(1974 / 75):$}} & $g y^{-1}$ & (wet mass) & & 36323.79 & 14848.49 & - & - \\
\hline & & $\mathrm{g} \mathrm{Y}^{-1}$ & (dry mass) & & 6486.39 & 2651.52 & 2039.24 & 864.34 \\
\hline & & $g m^{-2} Y^{-1}$ & (dry mass) & & 3.94 & 1.61 & 1.24 & 0.53 \\
\hline & & $\mathrm{kJ} \mathrm{m}^{-2} \mathrm{y}^{-1}$ & & & 87.74 & 35.87 & 22.73 & 17.47 \\
\hline \multirow{4}{*}{\multicolumn{2}{|c|}{ Totals $(1975 / 76)$ : }} & $g y^{-1}$ & (wet mass) & & 14613.19 & 5183.81 & - & - \\
\hline & & $g y^{-1}$ & (dry mass) & & 2609.50 & 925.68 & 472.47 & 343.58 \\
\hline & & $\mathrm{g} \mathrm{m}^{-2} \mathrm{y}^{-1}$ & (dry mass) & & 1.58 & 0.56 & 0.29 & 0.21 \\
\hline & & $\mathrm{kJ} \mathrm{m}^{-2} \mathrm{y}^{-1}$ & & & 35.30 & 12.52 & 7.75 & 6.94 \\
\hline \multirow{4}{*}{\multicolumn{2}{|c|}{ Totals $(1976 / 77)$}} & $g y^{-1}$ & (wet mass) & & 8382.71 & 4971.37 & - & - \\
\hline & & $g y^{-1}$ & (dry mass) & & 1496.91 & 887.74 & 694.07 & 105.00 \\
\hline & & $g m^{-2} y^{-1}$ & (dry mass) & & 0.91 & 0.54 & 0.42 & 0.06 \\
\hline & & $\mathrm{kJ} \mathrm{mi}^{-2} \mathrm{y}^{-1}$ & & & 20.25 & 12.01 & 7.74 & 2.12 \\
\hline
\end{tabular}

Table 4. Panulirus homarus. Male annual production rate $\left(P_{1}\right)$ and production rates for dry exoskeleton (exuviae) organics $\left(P_{2}\right)_{i}$ spermatophoric mass corrected for repetitive breeding $\left(P_{3}\right)$ for each size class

\begin{tabular}{|c|c|c|c|c|c|c|}
\hline Totals & & & $\bar{B}$ & $P_{1}$ & $P_{2}$ & $P_{3}$ \\
\hline Totals $(1974 / 75)$ : & $\begin{array}{r}g y^{-1} \\
g y^{-1} \\
g m^{-2} y^{-1} \\
\mathrm{~kJ} \mathrm{~m}^{-2} y^{-1}\end{array}$ & $\begin{array}{l}\text { (wet mass) } \\
\text { (dry mass) } \\
\text { (dry mass) }\end{array}$ & $\begin{array}{r}49385.20 \\
8818.79 \\
5.36 \\
119.29\end{array}$ & $\begin{array}{r}20317.32 \\
3628.09 \\
2.20 \\
49.08\end{array}$ & $\begin{array}{r}2408.54 \\
1.46 \\
26.85\end{array}$ & $\begin{array}{r}198.14 \\
102.56 \\
0.06 \\
1.74\end{array}$ \\
\hline Totals $(1975 / 76)$ : & $\begin{array}{r}g y^{-1} \\
g y^{-1} \\
g m^{-2} y^{-1} \\
k J m^{-2} y^{-1}\end{array}$ & $\begin{array}{l}\text { (wet mass) } \\
\text { (dry mass) } \\
\text { (dry mass) }\end{array}$ & $\begin{array}{r}17880.72 \\
3192.99 \\
1.94 \\
43.19\end{array}$ & $\begin{array}{r}7278.15 \\
1299.67 \\
0.79 \\
17.58\end{array}$ & $\begin{array}{r}- \\
904.42 \\
0.55 \\
10.01\end{array}$ & $\begin{array}{r}75.84 \\
38.86 \\
0.02 \\
0.66\end{array}$ \\
\hline Totals $(1976 / 77)$ : & $\begin{array}{r}\mathrm{g} y^{-1} \\
\mathrm{~g} y^{-1} \\
\mathrm{~g} \mathrm{~m} \mathrm{~m}^{-2} y^{-1} \\
\mathrm{~kJ} \mathrm{~m}^{-2} y^{-1}\end{array}$ & $\begin{array}{l}\text { (wet mass) } \\
\text { (dry mass) } \\
\text { (dry mass) }\end{array}$ & $\begin{array}{r}12542.18 \\
2239.67 \\
1.36 \\
30.30\end{array}$ & $\begin{array}{r}6559.35 \\
1171.31 \\
0.71 \\
15.84\end{array}$ & $\begin{array}{r}- \\
836.53 \\
0.51 \\
9.33\end{array}$ & $\begin{array}{r}32.72 \\
16.95 \\
0.01 \\
0.29\end{array}$ \\
\hline
\end{tabular}


capable of opening increases in direct proportion to the size of the lobster. In view of this it was necessary to calculate what proportion of the mean standing crop of mussels was potentially available as food for each size of rock lobster. This is summarised in Figure 1. Mussel numbers and biomass available are those to the left of each vertical line and those unavailable are to the right for each size class of rock lobster, e.g. for a 50-59 mm carapace length lobster $47 \%$ of the total mussel biomass is available (all those up to $60-64 \mathrm{~mm}$ size class) which represent $95 \%$ of the total numbers of mussels on the reef.

For the rock lobster population as a whole the mean annual consumption rate was only $3.6 \%$ of the total available mussel flesh and this rate was not exceeded by any individual size class, indicating that on the basis of the maximum size of mussel that can be opened there was a surplus of flesh available to the rock lobster population. Moreover, this is on the basis of the 'standing' crop of mussel flesh. If it is considered

Table 5. Panulirus homarus. Summary of mean biomass $\left(\mathrm{kJ} \mathrm{m}^{-2}\right)$, production rates $\left(\mathrm{kJ} \mathrm{m}^{-2} \mathrm{y}^{-1}\right)$ and $P / \bar{B}$ ratios for whole-animals, plus production rates, $P / \bar{B}$ ratios and production rates of exuviae and gonadal output expressed as percentages of whole-animal production

\begin{tabular}{|c|c|c|c|c|c|c|c|c|c|}
\hline & \multicolumn{3}{|c|}{ Whole animal } & \multicolumn{3}{|c|}{ Exuviae } & \multicolumn{3}{|c|}{ Gonadal output } \\
\hline & $\bar{B}_{1}$ & $P_{1}$ & $\frac{P_{1}}{\bar{B}_{1}}$ & $P_{2}$ & $\frac{P_{2}}{\bar{B}_{2}}$ & $\begin{array}{c}P_{2} \text { as } \\
\% \text { of } P_{1}\end{array}$ & $P_{3}$ & $\frac{P_{3}}{\bar{B}_{3}}$ & $\begin{array}{c}P_{3} \text { as } \\
\% \text { of } P_{1}\end{array}$ \\
\hline $\begin{array}{l}1974 / 75 \\
\text { males }\end{array}$ & 119.29 & 49.08 & 0.41 & 26.85 & 1.43 & 54.71 & 1.74 & 0.50 & 3.54 \\
\hline females & 87.74 & 35.87 & 0.41 & 22.73 & 1.79 & 63.37 & 17.47 & 0.31 & 48.70 \\
\hline Total & 207.03 & 84.95 & & 49.58 & & 58.36 & 19.48 & & 22.92 \\
\hline $\begin{array}{l}1975 / 76 \\
\text { males }\end{array}$ & 43.19 & 17.58 & 0.41 & 10.01 & 1.46 & 56.94 & 0.66 & 0.50 & 3.75 \\
\hline females & 35.30 & 12.52 & 0.35 & 7.75 & 1.48 & 61.90 & 6.94 & 0.31 & 55.43 \\
\hline Total & 78.49 & 30.10 & & 17.76 & & 59.00 & 7.60 & & 25.25 \\
\hline $\begin{array}{l}1976 / 77 \\
\text { males }\end{array}$ & 30.30 & 15.84 & 0.51 & 9.33 & 2.09 & 58.90 & 0.29 & 0.44 & 1.83 \\
\hline females & 20.25 & 12.01 & 0.59 & 7.74 & 2.65 & 64.45 & 2.12 & 0.23 & 17.65 \\
\hline Total & 50.55 & 27.85 & & 17.07 & & 61.29 & 2.41 & & 8.65 \\
\hline $\begin{array}{l}\text { Mean of } \\
3 \text { years }\end{array}$ & 112.02 & 47.63 & 0.42 & 28.14 & & 59.07 & 9.83 & & 20.64 \\
\hline
\end{tabular}

Table 6. Comparison of density and biomass between several palinurid lobster species of the genera Panulirus and Jasus

\begin{tabular}{|c|c|c|c|c|c|}
\hline Species & $\begin{array}{l}\text { Density } \\
\text { (No. } \mathrm{m}^{-2} \text { ) }\end{array}$ & $\begin{array}{l}\text { Wet biomass } \\
\qquad\left(\mathrm{gm}^{-2}\right)\end{array}$ & Locality & Method & Source \\
\hline P. homarus & $\begin{array}{c}0.13 \\
(0.35-0.04)\end{array}$ & 28.17 & $\begin{array}{l}\text { ORI Reef, S. Africa } \\
\text { (sanctuary) }\end{array}$ & Diving & $\begin{array}{l}\text { Present } \\
\text { study }\end{array}$ \\
\hline J. lalandii & 0.81 & 230 & $\begin{array}{l}\text { Robben Island, } \\
\text { S. Africa } \\
\text { (sanctuary) }\end{array}$ & Diving & $\begin{array}{l}\text { Pollock } \\
\text { (1979) }\end{array}$ \\
\hline P. cygnus & $\begin{array}{c}0.10 \\
(0.04-0.21)\end{array}$ & - & $\begin{array}{l}\text { Abrolhos Island, } \\
\text { W. Australia } \\
\text { (closed area in } \\
\text { fishing ground) }\end{array}$ & $\begin{array}{l}\text { Tag/ } \\
\text { recapture }\end{array}$ & $\begin{array}{l}\text { Morgan } \\
(1974)\end{array}$ \\
\hline $\begin{array}{l}\text { P. cygnus } \\
\text { (juv.) }\end{array}$ & $0.12-0.54$ & - & $\begin{array}{l}\text { Garden Island, } \\
\text { W. Australia } \\
\text { (sanctuary) }\end{array}$ & $\begin{array}{l}\text { Tag/ } \\
\text { recapture }\end{array}$ & $\begin{array}{l}\text { Chittleborough } \\
(1970)\end{array}$ \\
\hline$P$. argus & 0.0065 & 5.8 & $\begin{array}{l}\text { Dry Tortugas, } \\
\text { USA } \\
\text { (sanctuary) }\end{array}$ & $\begin{array}{l}\text { Diving/ } \\
\text { tagging }\end{array}$ & $\begin{array}{l}\text { Davis } \\
(1977)\end{array}$ \\
\hline P. argus & 0.001 & - & $\begin{array}{l}\text { St. John, USA } \\
\text { (sanctuary) }\end{array}$ & $\begin{array}{l}\text { Diving/ } \\
\text { tagging }\end{array}$ & $\begin{array}{l}\text { Olsen et al. } \\
(1975)\end{array}$ \\
\hline
\end{tabular}


that the mean $P \bar{B}$ ratio for the whole mussel population of the ORI Reef exceeds 3 and for the first year of growth may be as high as 6 (Berry, 1978) the available food is even greater, particularly for small lobsters. This situation was the case throughout the year as with spring and winter settlements the biomass and size composition of Perna perna on the ORI Reef remained fairly constant (Berry, 1978).

Smale (1978) also showed that there is a linear relationship between size of rock lobsters and the size of mussels selected as a first choice from a range. Using this relationship, the proportion of the mussel population available as first choice food was again determined. On this basis a mean of $14.3 \%$ of the total available population was consumed per annum and the maximum proportion was $32 \%$ for the $30-39 \mathrm{~mm}$ carapace length size class.

\section{DISCUSSION}

There are few published records of density and biomass in palinurid lobsters. Most of these are summarized in Table 6. Fluctuations in the density of Panulirus homarus on the ORI Reef in the twelve consecutive samples and between the three years sampled were substantial with coefficients of variation for the latter of $59.8 \%, 23.9 \%$ and $49.0 \%$, respectively. This is attributed mainly to large-scale sand movements which affect the availability of shelter for lobsters on the reef (Smale, 1978). Considerable variation in standing crop, due largely to seasonal recruitment, has been recorded by other authors, e.g. Chittleborough (1970) and Morgan (1974). However, in P. homarus this was not evident and no substantial changes attributable to recruitment occurred in the size composition of samples.

While the density and biomass of Panulirus homarus on the ORI Reef are somewhat higher than have been recorded in other members of the genus Panulirus they are substantially lower than those recorded for Jasus lalandii by Pollock (1979). J. lalandii is, however, a comparatively slow growing, long-lived cold water species which could be expected to accumulate a high biomass in conditions of low mortality rate provided that adequate food and shelter are available which, according to Pollock (1979) is the situation at Robben Island. A high production rate of $30.3 \mathrm{~g} \mathrm{~m}^{-2} \mathrm{y}^{-1}$ for males and $2.8 \mathrm{~g} \mathrm{~m}^{-2} \mathrm{y}^{-1}$ for females (wet mass) has been recorded for $J$. lalandii by Pollock (1978) compared with equivalent values of $6.9 \mathrm{~g} \mathrm{~m}^{-2} \mathrm{y}^{-1}$ and $5.1 \mathrm{~g} \mathrm{~m}^{-2} \mathrm{y}^{-1}$, respectively for $P$. homarus. The high production rate of $J$. lalandii is apparently a function of its higher biomass as $P / \bar{B}$ ratios for males and females are 0.22 and 0.04 , respectively, as opposed to 0.43 and 0.42 . respectively, in $P$. homarus.

The results obtained for the production rate of Panulirus homarus are obviously determined by prevailing conditions on the ORI Reef which influence growth rate and biomass. However, as an excess of food appeared to be available it seems unlikely that growth rate would have been significantly different over the three years of investigation. The $P / \bar{B}$ ratios obtained for whole animal production rate show a reasonable degree of consistency, variations being attributable to differences in the population composition. The fact that there is not a great discrepancy in $P / \bar{B}$ ratios between the sexes in $P$. homarus as has been recorded in Jasus lalandii is probably because the difference in growth rates between the sexes is substantially less than that recorded by Pollock (1978) in $J$. lalandii.

Production rate estimates of gonadal products are necessarily very rough because of the lack of accurate determinations of the proportion of females in each size class that spawn 1,2, 3 or 4 times per year. In the case of males, application of the same correction for repetitive breeding as for females may result in a considerable difference from the true situation, as Panulirus homarus is polygamous (Berry, 1970) and a higher proportion of mating is probably done by large males than small ones. Nevertheless, the fact that values obtained for total production in males and females were similar suggests that the error introduced in the correction for repetitive breeding was not substantial.

The proportion of energy involved in egg production is relatively high - about $50 \%$ of the whole animal production rate in the first two years of the study and $18 \%$ in the third year, when a higher proportion of small females was present. A progressive increase in the proportion of production being channelled into egg production is evident with increase in size (Table 3) This is probably due to increasing brood size and number of broods produced per annum and would account for the progressive divergence in growth rates of the sexes recorded by Berry (1971).

The morphology and structure of the spermatophoric mass of Panulirus homarus has been described by Berry (1970). Its colour and consistency suggested that it was probably largely composed of $\mathrm{CaCO}_{3}$. However, in determination of its calorific value this was found not to be the case; it is almost entirely composed of organic material of surprisingly high energy content $\left(27.9 \mathrm{~kJ} \mathrm{~g}^{-1}\right)$.

The results demonstrate that moulting with successive complete loss of exoskeletons and the necessity to replace what has been lost in addition to the new growth added at each successive moult, is an inefficient means of growth. In fact on the basis of the 
present results, it utilizes, for the population as a whole, approximately four times more energy than is the case if exoskeleton production is calculated without taking into account the number of moults involved, i.e. as if it were a continuous growth process.

Although an attempt has been made to take into account the availability of the mean standing crop of mussel flesh as food for the rock lobster population, this may not reflect the actual situation as it is not known to what degree mussels are protected from predation by existing in dense aggregations. Another unknown factor is the extent to which excessive surge conditions caused by rough seas limit feeding activity. If this is substantial it is probable that Smale's (1978) consumption rates in which individually separated mussels were fed under calm tank conditions are overestimated. Nevertheless, it is considered unlikely that food availability limits the standing crop or growth rate of lobsters on the ORI Reef, particularly in view of the substantially higher mean biomass of Jasus lalandii supported by a lower biomass of mussels (Pollock, 1979).

Both Jasus lalandii and Panulirus homarus feed predominantly on the filter feeding mussels Aulacomaya ater and Perna perna, respectively. The availability of food to these mussels and hence their productivity is dependent in both cases on physical energy subsidies. In $A$. ater this is largely the southeasterly wind which upwells nutrient rich water resulting in plankton blooms (Pollock, 1979), while in the case of $P$. perna it is the wind-driven surf action in the littoral zone which ensures the availability of detritus as food (Berry, 1978). It is suggested that a reason that the stocks of $P$. homarus are smaller than those of J. lalandii may lie in the fact that the energy subsidy on which $P$. perna and consequently $P$. homarus are dependent is present over the restricted area of the nearshore zone. The size of the lobster population is, therefore, limited by the amount of reef in this zone where its food organism accurs. The energy subsidy on which $A$. ater and $J$. lalandii are dependent gives rise to a much larger scale phenomenon and affects primary productivity over a considerably greater area. A. ater and $J$. lalandii have a greater vertical distribution than their eastcoast counterparts and the total area inhabited by $J$. lalandii and its total biomass is consequently substantially larger. Thus $J$, lalandii with a comparatively lower turnover rate supports a large-scale fishery whereas $P$. homarus with a much higher tumover rate but lower total biomass does not.
Acknowledgements. This study was financially supported by the South African Association for Marine Biological Research, the South African National Committee for Oceanographic Research and the Natal Provincial Administration through the Natal Parks Board. We wish to thank C. Griffiths and D. Pollock for their critical comments.

\section{LITERATURE CITED}

Allen, K. R. (1950). The computation of production in fish populations. N. Z. Sci. Rev. 8: 89

Berry, P. F. (1970). Mating behaviour, oviposition and fertilization in the spiny lobster Panulirus homarus (Linnaeus). Invest. Rep. oceanogr. Res. Inst. 24: 1-16

Berry, P. F. (1971). The biology of the spiny lobster Panulirus homarus (Linnaeus) off the east coast of southern Africa. Invest. Rep. oceanogr. Res. Inst. 28: 1-75

Berry, P. F. (1978). Reproduction, growth and production in the mussel Perna perna (Linnaeus), on the east coast of South Africa. Invest. Rep. oceanogr. Res. Inst. 48: 1-28

Chittleborough, R. G. (1970). Studies on recruitment in the Western Australian rock lobster Panulirus longipes cygnus George: density and natural mortality of juveniles. Aust. J. mar. Freshwat. Res. 21: 131-148

Crisp, D. J. (1971). Energy flow measurements. In: Holme, N. A., McIntyre, A. D. (eds) Methods for the study of marine benthos. Blackwell, Oxford, pp. 197-279

Davis, G. E. (1977). Effects of recreational harvest on a spiny lobster Panulirus argus, population. Bull. mar. Sci. 27 : 223-236

Ivlev, V. S. (1966). The biological productivity of waters. J. Fish. Res. Bd Can. 23: 1727-1759. (Translation with annotations)

Morgan, G. R. (1974). Aspects of the population dynamics of the western rock lobster, Panulirus cygnus George. I. Estimation of population density. Aust. J. mar. Freshwat. Res. 25: 235-248

Olsen, D. A., Herrnkind, W. F., Cooper, R. A. (1975). Population dynamics, ecology and behaviour of spiny lobsters Panulins argus, of St John, U.S. v.I: (I) Introduction and general population characteristics. Sci. Bull. Nat. Hist. Mus. Los Ang. Cty 20: 11-16

Pollock, D. E. (1978). Growth and production rates of the rock lobster Jasus lalandii (H. Milne Edwards). Ph. D. thesis, University of the Witwatersrand

Pollock, D. E. (1979). Predator-prey relationships between the rock lobster Jasus lalandii and the mussel Aulacomya ater at Robben Island on the Cape West coast of Africa. Mar. Biol. 52: 347-356

Ricker, W. E. (1946). Production and utilization of fish populations. Ecol. Monogr. 16: 374-391

Ricker, W. E. (ed.) (1968). Methods for assessment of fish production in fresh waters. I.B.P. Handbook no. 3. Blackwell, Oxford

Smale, M. J. (1978). Migration, growth and feeding in the Natal rock lobster Panulirus homarus (Linnaeus). Invest. Rep. oceanogr. Res. Inst. 47: 1-56 